\title{
MANIFESTATION OF NUCLEAR CLUSTERIZATION IN COULOMB SUMS
}

\author{
A.Yu. Buki, I.S. Timchenko \\ National Science Center "Kharkov Institute of Physics \& Technology" \\ 1, Akademicheskaya St., Kharkov, 61108, Ukraine \\ e-mail: timchenko@kipt.kharkov.ua \\ Received January 19, 2018
}

The new experimental Coulomb sums values of ${ }^{6} \mathrm{Li}$ and ${ }^{7} \mathrm{Li}$ nuclei have been obtained at momentum transfers range $q=0.750 \div 1.000 \mathrm{fm}^{-1}$ and $q=0.750 \div 1.125 \mathrm{fm}^{-1}$, respectively, extending significantly the earlier reported momentum transfers range of Coulomb sums for these nuclei. The dependence of the ${ }^{6} \mathrm{Li}$ and ${ }^{7} \mathrm{Li}$ Coulomb sums on the momentum transferred is shown to differ substantially from same dependences for all the other investigated nuclei. It is suggested that the observed feature of the ${ }^{6} \mathrm{Li}$ and ${ }^{7} \mathrm{Li}$ Coulomb sums is related to a strong clusterization of these nuclei. The parameter $q_{\mathrm{p}}$ corresponding to the value of the momentum transferred, at which the Coulomb sum ceases to grow and remains constant for larger momentum transfers, is introduced. The values of the parameter $q_{\mathrm{p}}$ for the lithium isotopes nuclei were obtained $\left(q_{\mathrm{p}}\left({ }^{7} \mathrm{Li}\right)=1.20 \pm 0.10 \mathrm{fm}^{-1}\right.$ and $q_{\mathrm{p}}\left({ }^{7} \mathrm{Li}\right)=1.35$ $\left.\pm 0.10 \mathrm{fm}^{-1}\right)$, which are much lower than $q_{\mathrm{p}}$ of ${ }^{4} \mathrm{He},{ }^{12} \mathrm{C},{ }^{40} \mathrm{Ca},{ }^{48} \mathrm{Ca}$ and ${ }^{56} \mathrm{Fe}$ nuclei $\left(q_{\mathrm{p}} \approx 2 \mathrm{fm}^{-1}\right)$. The graph represented the $q_{\mathrm{p}}$ values of the nuclei as a function of the isolation parameter $\mathrm{x}$, which characterizing the degree of nuclear clusterization, is constructed. The obtained graph shows the explicit proportionality of the $q_{\mathrm{p}}$ dependence from the parameter $x$ and predicts the $q_{\mathrm{p}}$ value for the Coulomb sum of the ${ }^{9} \mathrm{Be}$ nucleus not yet measured.

KEY WORDS: Coulomb sum, lithium isotopes, light and medium nuclei, nuclear clusterization, cluster isolation parameter $x$

\section{ПРОЯВ КЛАСТЕРІЗАЦЇ̈ ЯДЕР В КУЛОНІВСЬКИХ СУМАХ} О.Ю. Буки, І.С. Тімченко

Національний Науковий Центр «Харківський фізико-технічний інститут» вул. Академічна, 1, м. Харків, 61108, Украӥна

Отримано нові експериментальні значення кулонівських сум ядер ${ }^{6} \mathrm{Li}$ та ${ }^{7} \mathrm{Li}$ в діапазоні переданих імпульсів $q=0,750 \div 1,000$ фм $^{-1}$ та $q=0,750 \div 1,125{\phi м^{-1}}^{2}$ відповідно, які суттєво розширюють діапазон по $q$ раніше опублікованих кулонівських сум цих ядер. Показано, що залежність кулонівських сум від переданого імпульсу ізотопів літію істотно відрізняються від таких же залежностей для всіх інших ядер. Висловлено припущення про те, що виявлена особливість кулонівських сум ядер ${ }^{6} \mathrm{Li}$ та ${ }^{7} \mathrm{Li}$ пов'язана з сильною кластерізацією цих ядер. Введено параметр $q_{\mathrm{p}}$, що відповідає значенню переданого імпульсу, при якому кулонівська сума перестає рости, і залишається незмінною при бі'льших переданих імпульсах. Отримано значення параметру $q_{\mathrm{p}}$ для ядер ізотопів літію $\left(q_{\mathrm{p}}\left({ }^{7} \mathrm{Li}\right)=1,20 \pm 0,10 \mathrm{fm}^{-1} \mathrm{Ta} q_{\mathrm{p}}\left({ }^{6} \mathrm{Li}\right)=1,35 \pm 0,10 \mathrm{fm}^{-1}\right)$, які значно нижчі, ніж $q_{\mathrm{p}}$ для ядер ${ }^{4} \mathrm{He},{ }^{12} \mathrm{C},{ }^{40} \mathrm{Ca},{ }^{48} \mathrm{Ca} \mathrm{ra}{ }^{56} \mathrm{Fe}\left(q_{\mathrm{p}} \approx 2 \mathrm{fm}^{-1}\right)$. Побудовано графік, на якому значення $q_{\mathrm{p}}$ низки ядер наведені як функція параметру відособленості $x$, що характеризує ступінь їх кластерізації. Цей графік показує явну пропорційність між величиною $q_{\mathrm{p}}$ та параметром $x$ передбачає значення $q_{\mathrm{p}}$ для ще не виміряної кулонівської суми ядра ${ }^{9} \mathrm{Be}$. КЛЮЧОВІ СЛОВА: кулонівська сума, ізотопи літію, легкі та середні ядра, кластерізація ядра, параметр відособленості $x$

\section{ПРОЯВЛЕНИЕ КЛАСТЕРИЗАЦИИ ЯДЕР В КУЛОНОВСКИХ СУММАХ \\ А.Ю. Буки, И.С. Тимченко}

Национальный Научный Центр "Харьковский физико-технический институт" ул. Академическая, 1, г. Харьков, 61108, Украина

Получены новые экспериментальные значения кулоновских сумм ядер ${ }^{6} \mathrm{Li}$ и ${ }^{7} \mathrm{Li}$ в диапазоне переданных импульсов $q=0,750 \div 1,000 \mathrm{fm}^{-1}$ и $q=0,750 \div 1,125 \mathrm{fm}^{-1}$, соответственно, которые существенно расширяют диапазон по $q$ ранее опубликованных кулоновских сумм этих ядер. Показано, что зависимость кулоновских сумм от переданного импульса ядер ${ }^{6} \mathrm{Li}$ и ${ }^{7} \mathrm{Li}$ существенно отличается от таких зависимостей для всех других ядер. Высказано предположение о том, что обнаруженная особенность кулоновских сумм ядер ${ }^{6} \mathrm{Li} \mathrm{и}{ }^{7} \mathrm{Li}$ связана с сильной кластеризацией этих ядер. Введён параметр $q_{\mathrm{p}}$, соответствующий значению переданного импульса, при котором кулоновская сумма перестаёт расти и остаётся постоянной при бо́льших переданных импульсах. Получены значения параметра $q_{\mathrm{p}}$ для ядер изотопов лития $\left(q_{\mathrm{p}}\left({ }^{7} \mathrm{Li}\right)=1,20 \pm\right.$ $0,10 \mathrm{fm}^{-1}$ и $\left.q_{\mathrm{p}}\left({ }^{6} \mathrm{Li}\right)=1,35 \pm 0,10 \mathrm{fm}^{-1}\right)$, которые значительно ниже, чем $q_{\mathrm{p}}$ ядер ${ }^{4} \mathrm{He},{ }^{12} \mathrm{C},{ }^{40} \mathrm{Ca},{ }^{48} \mathrm{Ca}$ и ${ }^{56} \mathrm{Fe}\left(q_{\mathrm{p}} \approx 2 \mathrm{fm}^{-1}\right)$. Построен график, на котором значения $q_{\mathrm{p}}$ ряда ядер представлены как функция параметра обособленности $x$ характеризующего степени их кластеризации. Этот график показывает явную пропорциональность величины $q_{\mathrm{p}}$ от параметра $x$ и предсказывает значение $q_{\mathrm{p}}$ для ещё не измеренной кулоновской суммы ядра ${ }^{9} \mathrm{Be}$.

КЛЮЧЕВЫЕ СЛОВА: кулоновская сумма, изотопы лития, легкие и средние ядра, кластеризация ядра, параметр обособленности $x$

In the double-differential cross-section for electron scattering by the nucleus, $\left(\mathrm{d}^{2} \sigma / \mathrm{d} \Omega \mathrm{d} \omega\right)$, the contributions from the electron-nucleus interaction may be separated by means of longitudinal and transverse components of the electromagnetic field. Accordingly, these contributions are called the longitudinal and transverse response functions $R_{\mathrm{L}}(q, \omega)$ and $R_{\mathrm{T}}(q, \omega)$, respectively. According to [1], the double-differential cross-section is related to the response functions by the equation 


$$
\frac{d^{2} \sigma}{d \Omega d \omega}\left(\theta, E_{0}, \omega\right)=\sigma_{M}\left(\theta, E_{0}\right)\left\{\frac{Q^{4}}{q^{4}} R_{L}(q, \omega)+\left[\frac{1}{2} \frac{Q^{2}}{q^{2}}+\operatorname{tg}^{2} \frac{\theta}{2}\right] R_{T}(q, \omega)\right\},
$$

where $\omega, q, Q=\left(q^{2}-\omega^{2}\right)^{1 / 2}$ are, respectively, the energy, 3-momentum, 4-momentum transferred to the nucleus by the incident electron of initial energy $E_{0}$ and scattered by the angle $\theta ; \sigma_{\mathrm{M}}\left(E_{0}, \theta\right)=e^{4} \cos ^{2}(\theta / 2) /\left[4 E_{0}^{2} \sin ^{4}(\theta / 2)\right]$ is the Mott cross-section; $e$ is the electron charge.

In the treatment of the experimental data, one must take into account the influence of the nuclear electrostatic field on the incident electron. For this purpose, the correction $\Delta E_{0}$ is introduced into the definition of the 3-momentum transfer $q=\left\{4\left(E_{0}+\Delta E_{0}\right)\left[\left(E_{0}+\Delta E_{0}\right)-\omega\right] \sin ^{2}(\theta / 2)+\omega^{2}\right\}^{1 / 2}$. The correction $\Delta E_{0}$ is given by $k(3 / 2) Z \mathrm{e}^{2} / R$, where $R$ is the radius of the equivalent homogeneous distribution. According to [2], for electrons scattered by light nuclei to the continuum region the coefficient $k$ is equal to 0.8 .

The experimental data on the longitudinal functions $R_{\mathrm{L}}(q, \omega)$ are generally represented as Coulomb sum

$$
S_{L}(q)=\int_{\omega_{e l}^{+}}^{\infty} \frac{R_{L}(q, \omega)}{\left[\tilde{G}_{E}\left(Q^{2}\right)\right]^{2}} d \omega
$$

where $\left[\tilde{G}_{E}\left(Q^{2}\right)\right]^{2}=Z \eta\left(\left[G_{E}^{p}\left(Q^{2}\right)\right]^{2}+\frac{N}{Z}\left[G_{E}^{n}\left(Q^{2}\right)\right]^{2}\right)$. Here, $\omega_{e l}^{+}$, being the lower limit of integral (2), corresponds to the energy transfer of the elastic electron scattering peak, and the superscript "+" excludes the contribution of this peak to the integral; $N$ and $Z$ denote the number of neutrons and protons in the nucleus, respectively; $\eta=$ $\left[1+Q^{2} /\left(4 M^{2}\right)\right] \times\left[1+Q^{2} /\left(2 M^{2}\right)\right]^{-1}$ is the correction for the relativistic effect of nucleon motion in the nucleus; $M$ is the proton mass; $G_{E}^{p}$ and $G_{E}^{n}$ are the charge form factors of the proton and the neutron, respectively.

For all the nuclei studied, the behavior of $S_{\mathrm{L}}(q)$ with variations in the momentum transfer is similar in its character. With an increase in $q$, the $S_{\mathrm{L}}(q)$ increases until at a certain momentum transfer value denoted as $q_{p}$, the $S_{\mathrm{L}}(q)$ takes on constant values forming the function $S_{\mathrm{L}}(q)$ plateau. For almost all previously studied nuclei we have $q_{\mathrm{p}} \approx 2 \mathrm{fm}^{-1}$. By way of illustration, Fig. 1 shows the experimental $S_{\mathrm{L}}(q)$ values for the ${ }^{4} \mathrm{He}$ nucleus $[3,4,5]$.

The authors of papers $[6,7]$ have determined $S_{\mathrm{L}}(q)$ values for the ${ }^{6} \mathrm{Li}$ nucleus, and have found that the behavior of the function differs from the usual one (Fig. 1). It can be seen that the $S_{\mathrm{L}}(q)$ function reaches the plateau at $q_{\mathrm{p}} \approx 1.4 \mathrm{fm}^{-1}$, this being much earlier in $q$ than in the case with ${ }^{4} \mathrm{He}$ and other nuclei. In the ${ }^{7} \mathrm{Li}$ case, in the measurement range $q=$ $1.250 \div 1.625 \mathrm{fm}^{-1}$ [8], the function $S_{\mathrm{L}}(q)$ is constant within the experimental error and is equal to unity. It means that if the $S_{\mathrm{L}}(q)$ value is lower at certain momentum transfers, then it will reach the plateau range at $q_{\mathrm{p}} \leq 1.3 \mathrm{fm}^{-1}$. Thus, the data of [8] do not specify $q_{p}$ for the ${ }^{7} \mathrm{Li}$ nucleus, but restrict the upper value of this quantity. The authors of works [7, 8] have put forward the hypothesis that a comparatively low $q_{p}$ value in the ${ }^{6,7} \mathrm{Li}$ case may be due to the Coulomb sum manifestation of clusterization peculiar to the nuclei under discussion.

However, on a more rigorous approach to the problem of relationship between the $q_{p}$ value and nuclear

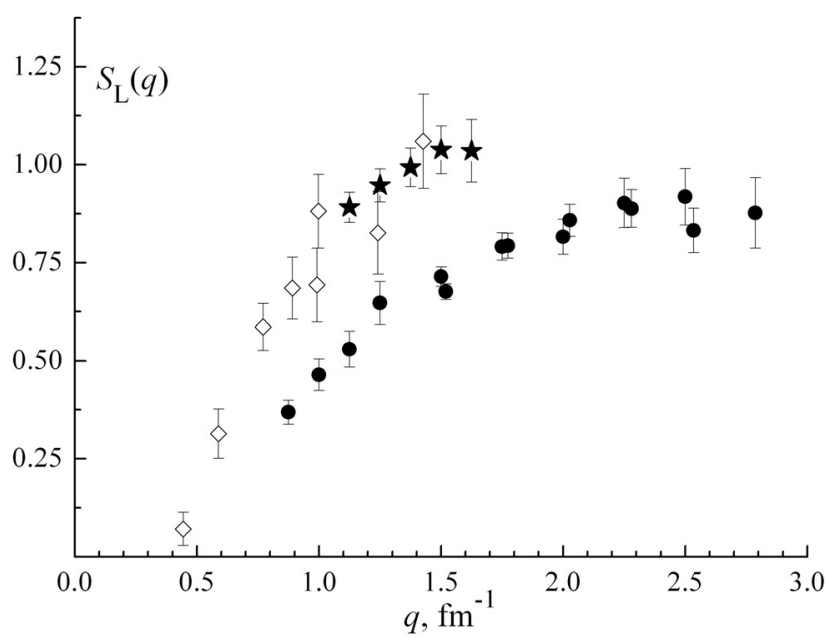

Fig. 1. Coulomb sums of ${ }^{4} \mathrm{He}$ and ${ }^{6} \mathrm{Li}$ nuclei. Full circles ${ }^{4} \mathrm{He}[3,4.5]$, diamonds $-{ }^{6} \mathrm{Li}[6]$, full asterisks $-{ }^{6} \mathrm{Li}[7]$. clusterization it should be noted that this hypothesis is actually based only on the experimental $q_{p}$ value of the ${ }^{6} \mathrm{Li}$ nucleus. As regards the $q_{p}$ value of ${ }^{7} \mathrm{Li}$, from the data of [8] it follows that it is not higher than that of ${ }^{6} \mathrm{Li}$, and it is not improbable that it may be substantially lower. The last version would be in contrast with the proposed hypothesis, because if the $q_{p}$ value is related to the clusterization (and the nuclei ${ }^{6} \mathrm{Li}$ and ${ }^{7} \mathrm{Li}$ are close in the degree of clusterization), then the $q_{p}$ values of these nuclei should also be little different from each other.

The aim of the present article is checking the hypothesis for the relationship between the nuclear clusterization and the momentum transfer value $q_{p}$. For the purpose it is necessary: a) to determine the $q_{p}$ value for the ${ }^{7} \mathrm{Li}$ nucleus; b) to define more exactly the $q_{p}$ value for the ${ }^{6} \mathrm{Li}$ nucleus; c) to obtain the $q_{p}$ values for the previously investigated nuclei. 
THE EXPERIMENT AND TREATMENT OF THE MEASURED DATA

The measurements, from which the present $S_{\mathrm{L}}(q)$ values were determined, were carried out at the experimental facility SP-95 with the use of the electron beam from the NSC KIPT electron linear accelerator LUE-300. The electron beam of monochromaticity between $0.4 \%$ and $0.6 \%$, and of energies ranging from 104 to $259 \mathrm{MeV}$, was incident on the ${ }^{6} \mathrm{Li}$ (or ${ }^{7} \mathrm{Li}$ ) target, the isotopic enrichment of which in the nuclide of interest was determined to be $90.5 \%$ (or $93.8 \%$ ),

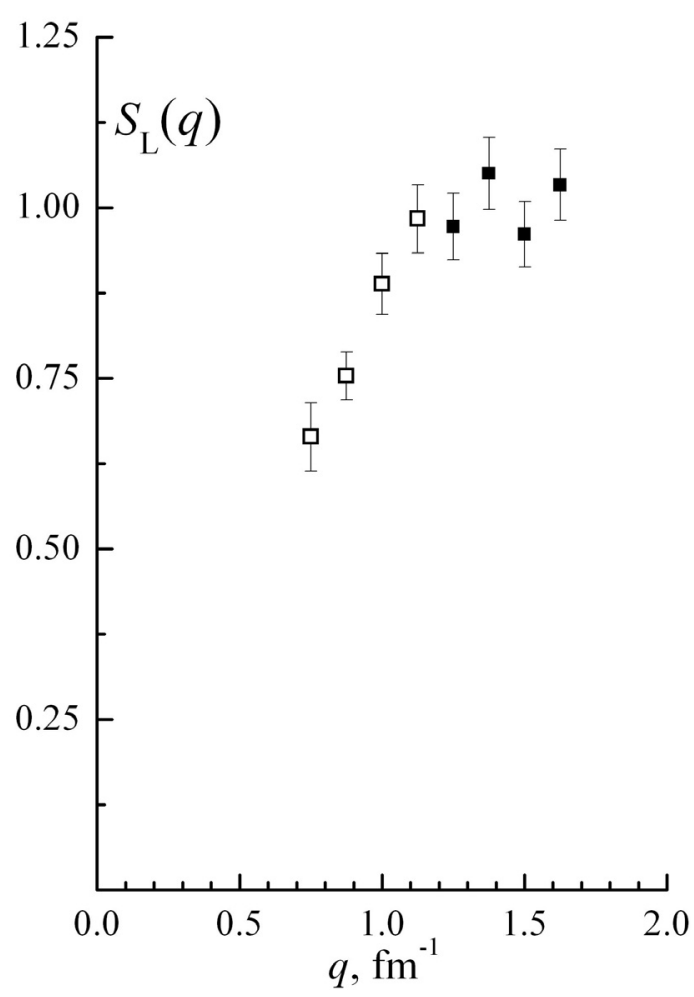

Fig. 2. Coulomb sum of ${ }^{7} \mathrm{Li}$. Full squares $-{ }^{7} \mathrm{Li}[8]$; open squares $-{ }^{7} \mathrm{Li}$ (present data).

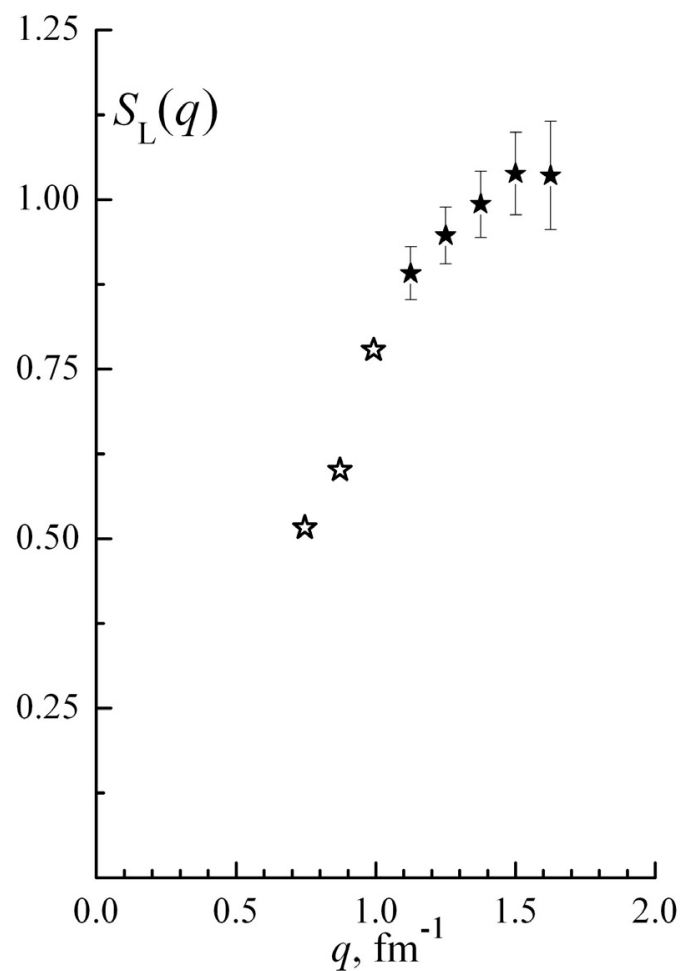

Fig. 3. Coulomb sum of ${ }^{6} \mathrm{Li}$. Full circles- ${ }^{6} \mathrm{Li}$ [7]; open circles $-{ }^{6} \mathrm{Li}$ (present data).

respectively. The measurements were performed at electron scattering angles from $34.2^{\circ}$ up to $160^{\circ}$. For momentum analysis of scattered electrons we have used the spectrometer that had the second-order double focusing in vertical and horizontal planes [9]. Electrons in the focal plane of the spectrometer were registered by the 8-channel scintillation Cherenkov counter [10]. The description of the facility has been given in several publications $[7,8,11,12]$.

The experiment was designed so that the response functions at several constant 3-momentum transfer values with $q$ ranging from 0.750 to $1.625 \mathrm{fm}^{-1}$, and also, the Coulomb sums corresponding to these functions, could be obtained from the measurements. It should be mentioned that the most complicated and labor-consuming stage in these experiments is the processing of the measurement results for yielding the response functions and the Coulomb sums. Taking into account the long duration of the processing, the work was planned so as to obtain first the data measured at the highest $q$ values, and then to process the data corresponding to lower momentum transfers. One of the advantages of this approach was the point that if the processing of a part of the experimental data yielded the physical data of prime interest, they could be discussed and submitted for publication at once, without waiting for the final processing of the whole body of initial measured data.

At the previous stage of measured data processing, we have obtained in this way four $S_{\mathrm{L}}(q)$ values for ${ }^{7} \mathrm{Li}$ at $q=$ $1.250 \ldots 1.625 \mathrm{fm}^{-1}[8]$, and five $S_{\mathrm{L}}(q)$ values for ${ }^{6} \mathrm{Li}$ at $q=1.125 \ldots 1.625 \mathrm{fm}^{-1}[7]$.

By the present time, in addition to the above-given values, we have obtained $S_{\mathrm{L}}(q)$ values for ${ }^{7} \mathrm{Li}$ at $q=0.750 \ldots$ $1.125 \mathrm{fm}^{-1}$ (Fig. 2), and preliminary $S_{\mathrm{L}}(q)$ values for ${ }^{6} \mathrm{Li}$ at $q=0.750 \ldots 1.000 \mathrm{fm}^{-1}$ (Fig. 3).

\section{NUCLEAR CLUSTERIZATION AND THE COULOMB SUM}

To analyze the relationship between the momentum transfer $q_{p}$ and the nuclear clusterization, the $q_{p}$ value determination must be formalized using a certain simple procedure, which will be applied to the experimental $S_{\mathrm{L}}(q)$ values of the nuclei under consideration. We define $q_{p}$ as the momentum transfer that corresponds to the point of intersection of two straight lines, one of which (horizontal) approximates the $S_{\mathrm{L}}(q)$ values on the plateau of $S_{\mathrm{L}}(q)$ as a function of $q$, and the other line approximates the $S_{\mathrm{L}}(q)$ values before reaching the plateau formation, starting from $S_{\mathrm{L}} \approx$ $2 / 3 \times S_{\mathrm{L}, \mathrm{p}}$, where $S_{\mathrm{L}, \mathrm{p}}$ is the $S_{\mathrm{L}}(q)$ value on the plateau. The given definition of the momentum transfer $q_{p}$ is exemplified by the $S_{\mathrm{L}}(q)$ for the ${ }^{4} \mathrm{He}$ nucleus (Fig. 4). 


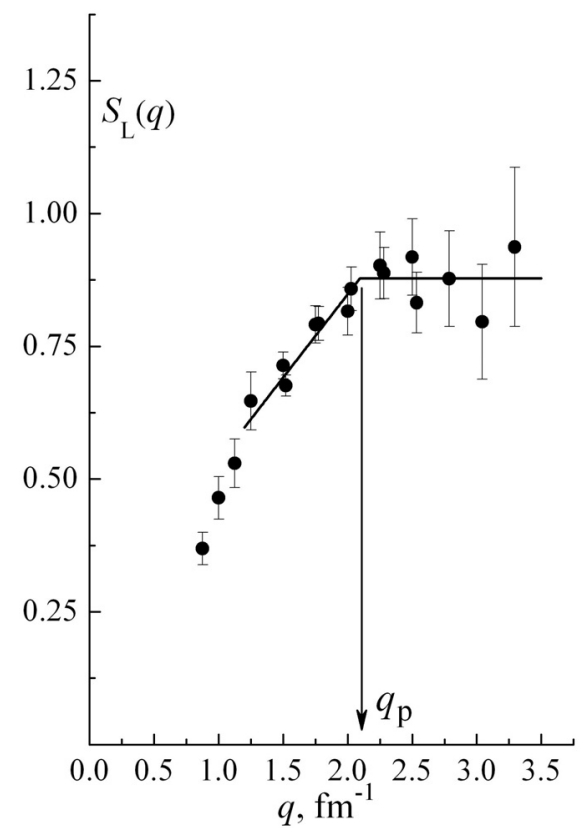

Fig. 4. Coulomb sum of ${ }^{4} \mathrm{He}$. Full circles $-{ }^{4} \mathrm{He}$ $[3,4,5]$; horizontal and inclined lines - data fitting; the intersection of the lines determines the $q_{\mathrm{p}}$ value.

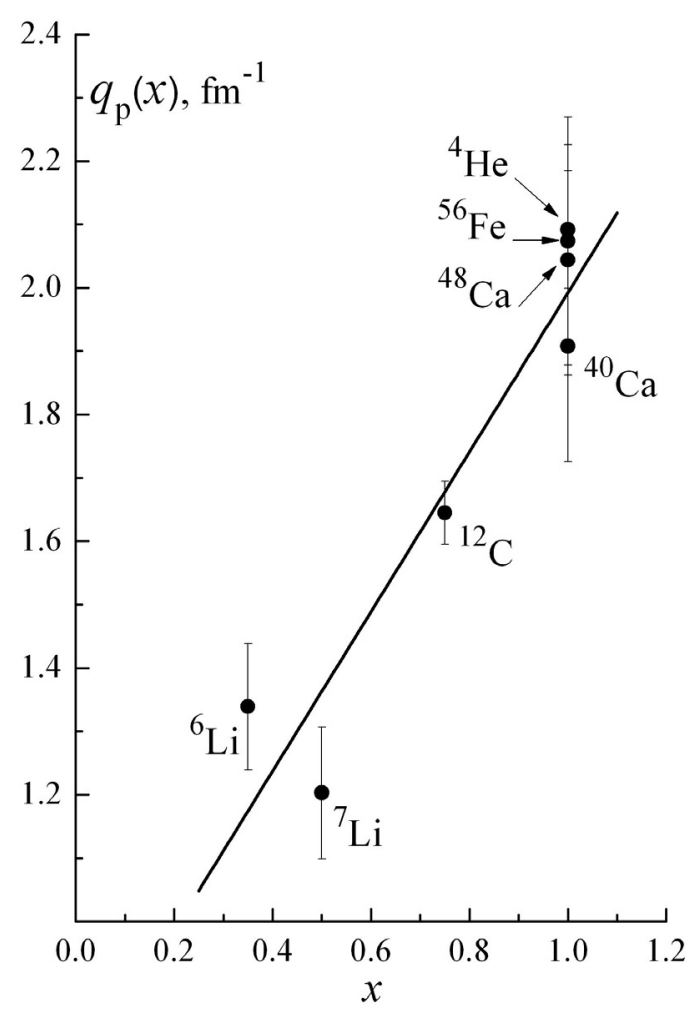

Fig. 6. Momentum transfer $q_{\mathrm{p}}$ versus the isolation parameter $x$ for different nuclei. The straight line represents the data fitting by the linear dependence.

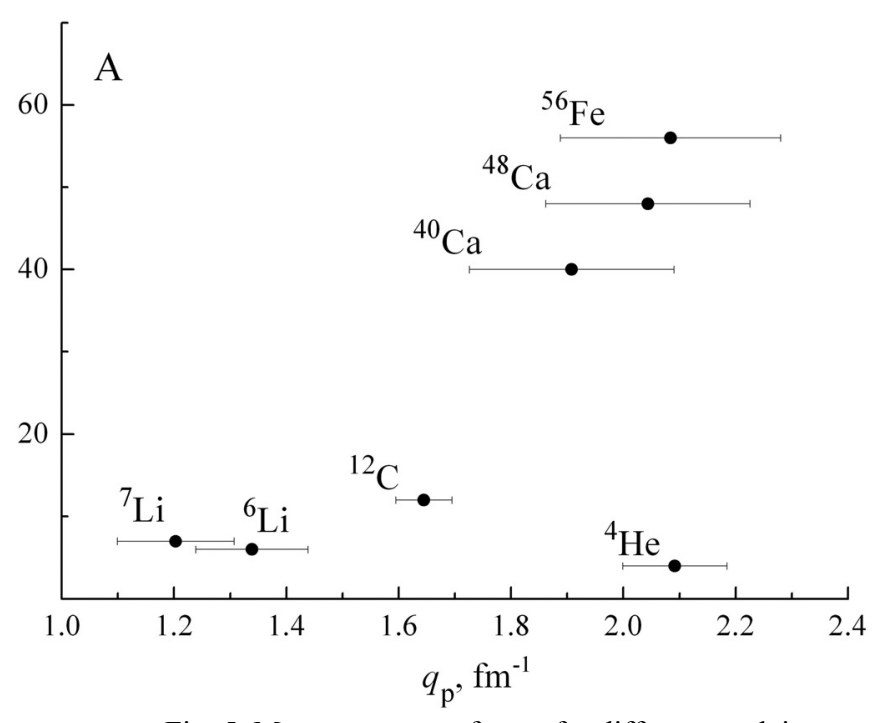

Fig. 5. Momentum transfers $q_{\mathrm{p}}$ for different nuclei with atomic mass $\mathrm{A}$.

We apply this definition of $q_{p}$ to all the nuclei having the atomic mass $A \geq 4$, for which a sufficient amount of experimental $S_{\mathrm{L}}(q)$ data is available known. These are the data of the present work and of our previous works on the nuclei ${ }^{6,7} \mathrm{Li}[6,7,8],{ }^{4} \mathrm{He}[3]$ and ${ }^{12} \mathrm{C}$ [13]. Besides, from [5], we have used the experimental $S_{\mathrm{L}}(q)$ data obtained at the Saclay and Bates Laboratories for ${ }^{4} \mathrm{He},{ }^{12} \mathrm{C},{ }^{40} \mathrm{Ca},{ }^{48} \mathrm{Ca},{ }^{56} \mathrm{Fe}$. The momentum transfers $q_{p}$ derived from these data are shown in Fig. 5. It can be seen that the $q_{p}$ values of the nuclei ${ }^{4} \mathrm{He},{ }^{40} \mathrm{Ca},{ }^{48} \mathrm{Ca},{ }^{56} \mathrm{Fe}$ are grouped at $q_{\mathrm{p}}=$ $(1.9 \ldots 2.1) \mathrm{fm}^{-1}$, and in the case of ${ }^{6} \mathrm{Li}$ and ${ }^{7} \mathrm{Li}-$ at $q_{\mathrm{p}}=$ $(1.20 \ldots 1.35) \mathrm{fm}^{-1}$. For the ${ }^{12} \mathrm{C}$ nucleus we have $q_{\mathrm{p}}=$ $1.65 \mathrm{fm}^{-1}$. The momentum $q_{p}$ grouping of the nuclei, observed in Fig. 5, corresponds to their distribution over the isolation parameter $x^{1 /}$. The first-group nuclei are not clusterized, whereas the second-group nuclei are strongly clusterized. For example, for the ${ }^{6} \mathrm{Li}$ nucleus, the parameter $x$ varies between 0.3 and $0.4[6,14,15]$, while for ${ }^{7} \mathrm{Li}$ we have $x=0.5$ [14]. With this approach, we arrive at understanding of the intermediate value (between the two groups) $q_{\mathrm{p}}=1.65 \mathrm{fm}^{-1}$ of the ${ }^{12} \mathrm{C}$ nucleus, which is clusterized substantially less than the nuclei of the lithium isotopes. For the ${ }^{12} \mathrm{C}$ nucleus, the parameter $x$ ranges from 0.7 to 0.8 [14].

Let us consider the momentum $q_{\mathrm{p}}$ as a function of the parameter $x$. For this purpose we put the isolation parameter of the nuclei ${ }^{4} \mathrm{He},{ }^{40} \mathrm{Ca},{ }^{48} \mathrm{Ca},{ }^{56} \mathrm{Fe}$ to be equal to 1.0. As is obvious from Fig. 6, the $x$ dependence of $q_{\mathrm{p}}$ is close to linear, this being in agreement with the result

\footnotetext{
${ }^{1 /}$ The isolation parameter of the nuclear cluster " $x$ " defines the degree to which the clusters are formed within the nucleus [14]. The $x$ value varies from $x=1$ (shell model, e.g., ${ }^{4} \mathrm{He}$ ) to $x=0$ (limiting case of the nuclear clusterization model).
} 
of fitting the straight line to all the data with the least $\chi_{i}^{2}$ value. Note that the observed dependence displays a high sensitivity of $q_{\mathrm{p}}$ to the $x$ value. After refinement of $q_{\mathrm{p}}(x)^{2 /}$, this feature of the function considered might be used for determination of $x$ from the $q_{\mathrm{p}}$ value. However, because of the laborious procedure of obtaining experimental Coulomb sums, this method would be hardly applicable in practice.

\section{RESULTS AND CONCLUSIONS}

The results of the present work can be summarized as follows.

A. Experimental $S_{\mathrm{L}}(q)$ values of the nuclei ${ }^{6} \mathrm{Li}$ and ${ }^{7} \mathrm{Li}$ have been obtained at momentum transfers $q=0.750 \ldots$ $1.000 \mathrm{fm}^{-1}$ and $q=0.750 \ldots 1.125 \mathrm{fm}^{-1}$, respectively. This has essentially extended the range of the measured $S_{\mathrm{L}}(q)$ towards $q$ values lower than those investigated in [7,8].

B. Using the $S_{\mathrm{L}}(q)$ data of the present work and of works [6-8], the momentum transfer $q_{\mathrm{p}}$ has been determined for the ${ }^{7} \mathrm{Li}$ nucleus $\left(q_{\mathrm{p}}=1.20 \pm 0.10 \mathrm{fm}^{-1}\right)$, and has been redetermined more exactly for the ${ }^{6} \mathrm{Li}$ nucleus $\left(q_{\mathrm{p}}=\right.$ $1.35 \pm 0.10 \mathrm{fm}^{-1}$ ). The analysis of the available literature data on the Coulomb sums for ${ }^{4} \mathrm{He},{ }^{12} \mathrm{C},{ }^{40} \mathrm{Ca},{ }^{48} \mathrm{Ca}$ and ${ }^{56} \mathrm{Fe}$ has yielded the $q_{\mathrm{p}}$ values for the mentioned nuclei (Fig. 5).

C. The momentum transfers $q_{\mathrm{p}}$ of nuclear lithium isotopes have been found to be much lower than those in the case of other nuclei.

The comparison of the present experimental data with the data obtained elsewhere for a number of nuclei has demonstrated the validity of the hypothesis as to the effect of nuclear clusterization on the Coulomb sum of the nucleus.

The effect manifests itself in the observable proportionality of the momentum transfer $q_{p}$ to the isolation parameter $x$, which characterizes the degree of nuclear clusterization. The hypothesis under discussion is also supported by the Coulomb sum measurement data for the ${ }^{9} \mathrm{Be}$ nucleus at $q=0.8 \ldots 1.7 \mathrm{fm}^{-1}$, from which the momentum $q_{\mathrm{p}}$ of this nucleus can be derived. Since the parameter $x=0.6$ [14], related to the ${ }^{9} \mathrm{Be}$ nucleus, lies between the $x$ values of the nuclei of lithium isotopes and the ones of ${ }^{12} \mathrm{C}$, then, according to the proposed hypothesis, its momentum transfer $q_{\mathrm{p}}$ should also lie between the $q_{\mathrm{p}}$ values of the mentioned nuclei, i.e., in the range from $1.3 \mathrm{fm}^{-1}$ to $1.6 \mathrm{fm}^{-1}$.

\section{REFERENCES}

1. de Forest T. Jr., Walecka J.D. Electron Scattering and Nuclear Structure // Ann. Phys. NY. - 1966. - Vol.15. - No.57. P. 1-109.

2. Aste A. Coulomb distortion effects in quasi-elastic (e,e') scattering on heavy nuclei // Nucl. Phys. - 2008. - Vol.A806. P. 191-215.

3. Buki A.Yu., Timchenko I.S., Shevchenko N.G., Nenko I.A. Coulomb sums of the ${ }^{4} \mathrm{He}$ nucleus at $q=0.88$ to $1.25 \mathrm{fm}^{-1} / / \mathrm{Phys}$ Lett. - 2006. - Vol.B641. - P. 156-158.

4. von Reden K.F., Alcorn C., Dytman S.A., et al. Quasielastic electron scattering and Coulomb sum rule in ${ }^{4} \mathrm{He} / / \mathrm{Phys}$. Rev. 1990. - Vol.C41. - P. 1084-1094.

5. Zghiche A., Danelet J.F., Bernhheim M., et al. Longitudinal and transverse responses in quasi-elastic electron scattering from ${ }^{208} \mathrm{~Pb}$ and ${ }^{4} \mathrm{He} / /$ Nucl. Phys. - 1994. - Vol.A572. - P. 513-559.

6. Buki A.Yu., Nenko I.A., Shevchenko N.G., Efros V.D. Experimental determination of the Coulomb energy of the nucleus ${ }^{6} \mathrm{Li} / /$ Sov. J. Nucl. Phys. - 1977. - Vol.25. - P. 246-247.

7. Buki A.Yu., Timchenko I.S., Shevchenko N.G. Saturation of Coulomb sum rules in the ${ }^{6} \mathrm{Li}$ case // Eur. Phys. J. - 2012. Vol.A48. - P. 17-22. DOI 10.1140/epja/i2012-12017-6.

8. Buki A.Yu., Shevchenko N.G., Timchenko I.S. Coulomb sums for ${ }^{7} \mathrm{Li}$ nucleus at 3-momentum transfers $q=1.250-1.625 \mathrm{fm}^{-1}$ // PAST. - 2009. - Vol.3(51). - P. 38-42.

9. Afanasiev N.G., Goldshtane V.A., Savitskiy G.A., et. al. Magnetic spectrometer for particles with momentum up to $400 \mathrm{MeV} / \mathrm{s}$ // I.E.T. - 1966. - Vol.5. - P. 44-50. (in Russian)

10. Polishchuk V.N., Shevchenko N.G., Afanas'ev N.G., et al. Multi-channel counter for registration high-energy electrons: Preprint KIPT 72-40. - 1972. - Kharkov. - 20p. (in Russian)

11. Buki A.Yu., Shevchenko N.G., Nenko I.A., et al. Moments of the response functions of the ${ }^{2} \mathrm{H}$ nucleus at $q=1.05 \mathrm{fm}^{-1} / / \mathrm{Phys}$ of At. Nucl. - 2002. - Vol.65(5). - P. 787-796.

12. Buki A.Yu., Shevchenko N.G., Polishchuk V.N., Khomich A.A. Transverse moment of the ${ }^{4}$ He response function at transfered momentum $0.75 \div 1.5 \mathrm{fm}^{-1} / /$ Phys. of At. Nucl. -1995 . - Vol.58(8). - P. 1353-1361.

13. Buki A.Yu. Coulomb sum of ${ }^{12} \mathrm{C}$ nucleus at transferred momentum $0.95 \div 1.35 \mathrm{fm}^{-1} / /$ The Journal of Kharkiv National University. Series: "Nuclei, Particles, Fields". - 2010. - Vol. 48. - P. 37-40. (in Russian)

14. Überall H. Electron Scattering From Complex Nuclei. Part A. - Academic Press: New York and London, 1971. (look page 368)

15. Krumova G.Z., Tomasi-Gustafsson E., Antonov A.N. Charge form factor and cluster structure of the 6Li nucleus // Open Phys. - 2008. - Vol.6. - P. 491-497. DOI: 10.2478/s11534-008-0091-4, arXiv:0709.1016v1 [nucl-th].

\footnotetext{
${ }^{2 /}$ In particular, checking of $x$ values for the nuclei of lithium isotopes.
} 